\title{
Anti-Poliovirus Antibody Positive
}

National Cancer Institute

\section{Source}

National Cancer Institute. Anti-Poliovirus Antibody Positive. NCI Thesaurus. Code C157115.

An indication that antibodies that recognize poliovirus have been detected in a sample. 